\title{
JUDICIAL REVIEW AND CHURCH COURTS IN THE LAW OF SCOTLAND
}

\author{
Frank Cranmer*
}

\section{INTRODUCTION}

Until now, it has been a long-settled principle of Scots law that there is one Church recognised by law - the Church of Scotland - with proper courts in the full legal sense of that term, and a series of private ecclesiastical organisations with tribunals of no particular legal standing. ${ }^{1}$ Therefore:
"The courts of the Church of Scotland are legally established courts of the realm whereas courts of other Churches have jurisdiction only so far as conferred by their own constitutions and the adherence of their members. No claim for damages lies in the Court of Session against a Church court for a judgment in a proper case of discipline duly brought before it. The civil courts are bound to assist the Church courts in making their decrees effectual, but cannot review their decisions in matters falling within their jurisdiction."2

Similarly, because they are a fully-recognised branch of the system of courts, they share the powers and privileges of the civil courts. The General Assembly as the Supreme Court shares with the Inner House of the Court of Session the power to reduce its own decrees and, like the Court of Session and the High

"I would like to express my thanks to Francis Coleman for reading this article in draft and giving me the benefit of his views. The conclusions, however, are my own.

${ }^{1}$ For the history of Establishment in Scotland, see C.R.Munro, "Does Scotland have an Established Church?" (1997) 4 Journal of Ecclesiastical Law 639.

${ }^{2}$ D.M.Walker, The Scottish Legal System ( $6^{\text {th }}$ ed., 1992, W.Green) at 311-2. See also Munro, ibid. at 645. 


\section{THE DENNING LAW JOURNAL}

Court of Justiciary, exercises the nobile officium. ${ }^{3}$

The proceedings of the courts of the Kirk also enjoy considerable protection from actions for defamation.

"When the General Assembly exercises judicial functions in relation to matters properly brought before that court, persons engaged in the proceedings are probably protected by absolute privilege... It is settled law that no court of the Church of Scotland may be sued in respect of any judgment or sentence pronounced in any cause duly brought before it, regularly conducted and within its jurisdiction." ${ }^{34}$

It should be noted, however, that this immunity extends only to the courts of the Kirk when they are acting in a judicial capacity. Andrew Herron suggests that, since much of their business is non-judicial, before any statement is made to which exception might be taken, the members of any Church court would be wise to consider carefully whether such a statement might be factually inaccurate or construed as malicious. ${ }^{5}$

All this is well-understood. However, there has been one area in which the position of Church courts of all denominations was not entirely clear: that of judicial review.

\section{THE EARLIER CASES}

The readiness of the Court of Session to distinguish between the actings of the courts of the Kirk and the decisions of the tribunals of nonconformist Churches was already becoming apparent from a series of decided cases which predate the Church of Scotland Act 1921.

In Lockhart v. Presbytery of Deer, Lord President Boyle stated that the courts of the Kirk possessed exclusive jurisdiction in ecclesiastical causes and that the Court of Session would not normally interfere with their decisions:

${ }^{3}$ An equitable power to supply a remedy where the existing law is silent; it is not, however, a power to set aside the existing law. See A.Herron, The Law and Practice of the Kirk (1995, Chapter House, Edinburgh) at 276; Walker, op cit, at 193.

${ }^{4}$ C.K.Davidson, "Church of Scotland" 3 Stair Memorial Encyclopaedia para. 1547, citing Sturrock v. Grieg (1849) 11 D. 1220 \& Wight v. Presbytery of Dunkeld (1870) 8 M. 921.

${ }^{5}$ Herron, supra.n. 3 at 277. 


\title{
JUDICIAL REVIEW AND CHURCH COURTS
}

"We have as little right to interfere with the procedure of the Church courts in matters of ecclesiastical discipline as we have to interfere with the proceedings of the Court of Justiciary in a criminal question."

In Wight v. Presbytery of Dunkeld the Court of Session agreed that the proceedings in the Presbytery of which the pursuer complained were irregular, contrary to the laws and practice of the Church, and altogether null. Nevertheless, Lord Justice Clerk Moncrieff refused to set them aside:

\begin{abstract}
"If... this were a case in which we were called upon to review the proceedings of an inferior court, I should have thought a strong case had been made for our interference. But whatever inconsiderate dicta to that effect may have been thrown out, that is not the law of Scotland. The jurisdiction of the Church courts, as recognised judicatories of this realm, rests on a similar statutory foundation to that under which we administer justice within these walls... Within their spiritual province the Church courts are as supreme as we are within the civil; and as this is a matter relating to the discipline of the Church, and solely within the cognisance of the Church courts, I think we have no power whatever to interfere."
\end{abstract}

On the other hand, the attitude of the Court of Session to the tribunals of nonconformist Churches has been much more equivocal. Even though such tribunals are unofficial, in Auchinloss v. Black, Lord Justice Clerk Braxfield nevertheless refused in a case involving the Secession Church "to review the proceedings of the Associate Congregation, commonly called Burghers, when sentences are pronounced by them in their ecclesiastical character."9

Not long afterwards, however, in Drummond v. Farquar the designation of the pursuer, Drummond, as "one of the bishops or senior clergymen of the superior order of the Episcopal communion in Scotland" was struck out as "not

${ }^{6}(1851) 13$ D. 1296 at 1299.

7 Supra.n.4 at 925 per Lord Cowan.

${ }^{8}$ lbid.

${ }^{9}$ Hume, Decisions, $6^{\text {th }}$ March, 1793. 


\section{THE DENNING LAW JOURNAL}

recognised by the court", ${ }^{10}$ while in Dunbar v. Skinner ${ }^{11}$ Lord President Boyle ruled that "there exists in Scotland no Episcopal Church whatever except as a distinct sect, fully recognised and protected under the Toleration Act."12

In Mathers v. Laurie it was held that a Free Church Kirk Session Minute could not be adduced as conclusive evidence of itself, since the tribunal concerned was not a court of law; parole evidence had to be led to prove the Minute. ${ }^{13}$

Notwithstanding this distinction, however, the Court of Session has in practice been reluctant to interfere with the decisions of nonconformist tribunals, seemingly on the grounds that such a tribunal is the duly-constituted regulatory and disciplinary body of a voluntary association and that the members, by virtue of their membership, enter into a contractual obligation to submit to its decisions. ${ }^{14}$ There is therefore a line of decided cases which suggest that the Court of Session will normally intervene only when a civil, rather than an ecclesiastical, wrong has been committed.

In Forbes v. Eden, the Rector of Burntisland brought an act against the Primus and others of the General Synod of the Episcopal Church, averring that, in adopting a code of canon law in 1862 which inter alia substituted the English Communion Rite of 1662 for the Scots Rite of 1764, Synod had acted ultra vires. ${ }^{15}$ The pursuer concluded for reduction, i.e. annulment, of the new canons; however, the pursuer's pleas were dismissed by the Lord Ordinary.

On reclaimer, i.e. appeal to the Inner House, the pursuer's arguments were again rejected by the Inner House on the grounds of irrelevance. Lord Cowan went further in his obiter:

"I cannot but regard it as an entire novelty to ask courts of law to determine whether the ruling judicatory of a voluntary Church acted within its powers in matters so purely and exclusively relating to the

${ }^{10}$ Faculty Collection, 6th.July, 1809 - see F.Lyall, Of presbyters and kings (1980, Aberdeen University Press) at 88.

${ }^{11}$ (1849) 11 D. 945.

${ }^{12}$ i.e the Scottish Episcopalians Act 1711.

${ }^{13}$ (1849) 12 D. 433.

${ }^{14}$ Osborne v. Southern Reformed Presbytery (1831) Outer House (unreported) - see Lyall, supra.n. 10 at 91 .

${ }^{15}$ (1865) 4 M. 143. 


\section{JUDICIAL REVIEW AND CHURCH COURTS}

government of the body as a Church, its doctrines and discipline... When the ecclesiastical governing body has recognised changes either in doctrinal matters, or in the rights [sic] and ceremonies of the church, dissentient laymen may leave its communion. Their remedy cannot be to bring the resolutions of the church judicatory into a court of law, as a court of review. Some civil wrong justifying a demand for redress, or some patrimonial injury entitling the party to claim damages, must be alleged and instructed, ere the civil court entertain and adjudicate in such cases. This is the principle which pervades the whole of the cases of this class. "16

Equally, in Skerret v. Oliver, the First Division refused to reinstate a licentiate of the United Presbyterian Church who had been suspended and deprived by the U.P. Synod "for having, under certain circumstances, met and walked with a young lady" on the grounds that "courts of law take no concern with the resolutions of voluntary associations except so far as they affect civil rights."17

An even narrower view was taken in McDonald v. Burns. ${ }^{18}$ Five extern Sisters of the Colettine Community of Poor Clares in Edinburgh had been dismissed from their convent by the Sacred Congregation of Religious in Rome, but refused to leave. The trustees of the Convent brought an action in the Court of Session for their removal from the convent. The defenders argued that they had been dismissed in contravention of the statute of their Order regarding the dismissal of extern Sisters, in that no specific charges had been made against them and that they had been given no opportunity to respond. The Lord Ordinary [Robertson] having found for the pursuers, the defenders reclaimed.

In granting an interlocutor, Lord Justice Clerk Aitchison made the following general statement of the rights of ecclesiastical bodies to regulate their own affairs without judicial interference:

“...the limits...are strictly defined, and should not be incautiously extended. Where civil rights are concerned, appeal may be made to the courts of law for their protection, or for some form of redress, but the mere fact that a civil right is affected by itself forms no

\footnotetext{
${ }^{16} \mathrm{Ibid}$. at 163 [emphasis added].

${ }^{17}$ (1896) 3 S.L.T. 257 per Lord Robinson. It was a different world in those days.

${ }^{18} 1940$ S.C. 376
} 


\section{THE DENNING LAW JOURNAL}

justification for interference. for civil consequences may often result from decisions of ecclesiastical courts in matters that lie properly within their own jurisdiction. "19

There the matter might have rested; but the difference between the attitude of the Court of Session towards the courts of the Established Church and the tribunals of other religious bodies in Scotland has been highlighted most clearly by three recent cases: one involving the Free Presbyterian Church and the others involving the Kirk. In particular, the uncertainty over the degree to which the tribunals of dissenting Churches are obliged to abide by the rules of natural justice appears finally to have been resolved. ${ }^{20}$

\section{BRENTALL v. FREE PRESB YTERIAN CHURCH OF SCOTLAND 11}

In Brentall the facts were as follows. ${ }^{22}$ The Reverend John Brentall, together with the Reverend Moshe Radcliff, presented an Overture to his Presbytery raising the question of whether a Protest against a decision of the Synod of the Church might be necessary so that a person might exonerate his conscience. The Overture was rejected by Presbytery, and they took the matter to Synod - the Supreme Court of their Church.

At the Synod of May, 1980 the Overture was dismissed without discussion: Mr.Brentall and Mr.Radcliff then entered a Protest against the refusal of the Synod "of a scriptural discussion anent Protest," but stating that:

"we hereby declare that by this Protest we do in no way separate ourselves from the Free Presbyterian Church of Scotland or resign our respective charges or act contrary to our ordination vows or impugn the authority of this Venerable Court or call the integrity of this Venerable Court into question."

${ }^{19}$ Ibid at 381 [emphasis added].

${ }^{20}$ For a discussion of the uncertainties, see G.W.Patterson, "The law of Scotland and the decisions of the ecclesiastical courts" (1986) Juridical Review 152.

${ }^{21} 1986$ S.L.T. 470.

${ }^{22}$ For the narrative background to the case, see J.Macleod, No great mischief if you fall: the Highland experience (1993, Mainstream Publishing, Edinburgh). 


\section{JUDICIAL REVIEW AND CHURCH COURTS}

It should be remembered that "Protest" is a term of art in Presbyterian church law. It was by Protest that Thomas Chalmers, David Welsh and their colleagues initiated the Disruption in 1843, when they walked out of the General Assembly of the Kirk and founded the Free Church of Scotland. Moreover, it was by Protest against what they saw as the heretical stance of the Free Church Declaratory Act of 1892 towards liberty of opinion in the construction of the Westminster Confession, that Donald Macfarlane, Donald Macdonald and their colleagues separated themselves from the Free Church in 1893, and founded the Free Presbyterian Church. ${ }^{23}$ The precise effect of a Protest is therefore of enormous importance to the Free Presbyterian Church; the official view is that unless Macfarlane's Protest in 1893 had immediately separated him and his colleagues from the Free Church of the Declaratory Act, then the historical link with the "pure" pre-Declaratory Act Free Church would have been broken at that point, and the claim of the Free Presbyterian Church to be the one, true Reformed Church of Scotland would thereby be invalidated. ${ }^{24}$

Moreover, the Protest Question has been a matter of some controversy throughout the history of the Free Presbyterian Church. In 1944 Roderick Mackenzie expressed his disagreement with the Synod view of Protest and was thereby held to have separated himself from the Church - with the result that he founded the Free Presbyterian Relief Congregation. ${ }^{25}$ It was in 1944, therefore that the Free Presbyterian Church Synod published a statement on the nature of Protest which included the assertions that:

"A Protest in itself does not necessarily put the protester out of the Church; yet, a Protest tabled and persisted in against the decision of the Supreme Court cannot be received; [but] ... a Protest may and usually does involve the self-exclusion of the person protesting from the Supreme Court of the Church."

At the 1980 Synod on the occasion in question, the Clerk first asked Messrs

${ }^{23}$ It was by Protest and Deed of Separation that those who left the Free Presbyterian Church in 1989 in order to form the Associated Presbyterian Churches separated themselves from the F.P.C.

${ }^{24}$ Macleod, supra.n.22 at 103.

${ }^{25}$ See A. Morrison, "Protest Question," in N.M.de S.Cameron (ed.) Dictionary of Scottish Church History and Theology (1993, T.\& T. Clerk, Edinburgh). 
Brentall and Radcliff if they would change their Protest to a Dissent (which may be tendered simply to relieve the dissenter from any involvement in the decision of the court. $)^{26}$ When they refused to do so, the Clerk pointed out that, in accordance with the 1944 statement, a Protest against a decision of the Supreme Court could not be received. After deliberation, at part of which the complainers were not present, Synod then determined to discipline them and, it being clear that they had not changed their position, they were suspended sine die.

Mr.Brentall raised an action for the reduction of the resolutions to suspend him, with ancillary conclusions for interdict and reparation. ${ }^{27}$ There was no dispute between the parties as to the competence of the Court of Session to reduce as unlawful decisions of the Synod of the Free Presbyterian Church; however, the defenders argued that Synod had found Messrs Brentall and Radcliff guilty of contumacy and had therefore acted within its powers. ${ }^{28}$ The Lord Ordinary [Dunpark] dismissed the action.

The pursuer reclaimed, arguing that, in acting as it did, Synod had exceeded its own powers and had failed to observe the rules of natural justice. The Second Division held that the averments instructing a charge of contumacy were irrelevant and that, accordingly, the decision of the Synod to suspend the pursuer was null and void, on the grounds that it was contrary to natural justice. A decree of reduction was consequently granted.

The details of the charge of contumacy need not concern us, and the court declined to get involved in the theology of Protest - though Lord Robertson did quote with approval the obiter of Lord Guthrie in Mackay v. Macleod to the effect that the making of a Protest by a minister of the Church against a decision of Synod could not be construed as implying his separation from the Church, but merely his disapproval of the decision against which the Protest was made. ${ }^{29}$ What is of greater interest for the purposes of the present discussion, however, is the willingness of the court to examine the extent to which the Synod had complied with the rules of natural justice. Lord Justice Clerk Ross outlined the basic principles as follows:

\section{${ }^{26} \mathrm{Ibid}$.}

${ }^{27} \mathrm{Mr}$.Radcliff raised a separate action; it was agreed that the action, in effect, be sisted pending the outcome of Mr.Brentall's reclaimer.

${ }^{28}$ Supra.n.21 per Lord Robertson at 484.

${ }^{29}$ First Division, 10th.January, 1952, unreported. 


\title{
JUDICIAL REVIEW AND CHURCH COURTS
}

\begin{abstract}
"Natural justice has a number of facets, but it certainly includes the principle that a decision should not be taken against a party without that party having a fair opportunity to know what the case against him is and a fair opportunity to deal with the case."
\end{abstract}

- in short, audi alteram partem. The Lord Justice Clerk rejected the argument that a hearing before Synod would, in the circumstances be a useless formality, and quoted with approval Lord President Clyde in Barrs v. British Wool Marketing Board:

\begin{abstract}
"It is not a question of whether the Tribunal has arrived at a fair result - for in most cases that would involve an examination into the merits of the case upon which the Tribunal is final. The question is whether the Tribunal has dealt fairly and equally with the parties before it in arriving at the result. The test is not, has an unjust result been reached? but, was there an opportunity afforded for injustice to be done? If so, the decision cannot stand. ${ }^{\prime 31}$
\end{abstract}

The court therefore decided that the defenders had proceeded in breach of the rules of natural justice and, on that basis, found for the pursuer.

\section{$B U C H A N$ v. BRODIE $E^{32}$}

The question of the Court of Session's power of judicial review in the case of an alleged breach of natural justice by the Established Church itself had previously been raised in Buchan v. Brodie. No opinion had been issued in that case, and what follows are the facts as rehearsed by Lord Osborne in Logan v. Presbytery of Dumbarton. ${ }^{33}$

The petitioner, Buchan, had been an appellant to the Judicial Commission of the General Assembly of the Church of Scotland in relation to a matter of discipline. The Commission deliberated on the appeal but was inquorate when it

${ }^{30}$ Supra. n.21 at 482 .

${ }^{31} 1957$ S.L.T.153 at 157.

${ }^{32}$ Outer House, 15th. August, 1984, unreported.

${ }^{33} 1995$ S.L.T. 1228 at 1232; also noted in Davidson, supra.n.4 at para. 1505 n.2. 
did so. On the advice of the Procurator, the General Assembly declared the earlier proceedings null and void and remitted the case to the Judicial Commission for rehearing. The petitioner then applied to the Court of Session for interim interdict, pending full hearing, to prevent the Commission from proceeding, on the grounds that members of the Commission who had sat on the earlier appeal had already made up their minds and that it was contrary to natural justice that they should rehear the appeal. The answer to the petition contained a plea of no jurisdiction, citing Article IV of the Articles Declaratory to the Church of Scotland Act 1921. Interim interdict was refused.

\section{LOGAN v.PRESBYTERY OF DUMBARTON ${ }^{34}$}

The current position under the common law as regards judicial review of the actings of the courts of the Established Church appears to be that stated in Logan v. Presbytery of Dumbarton. Mr.Logan was Parish Minister at Abbotsford, Clydebank. He had been running a business from his manse, and when he applied retrospectively to the Presbytery for permission to do so, it was refused. He gave assurances that he would abide by the decision of Presbytery; but, it was libelled in the subsequent hearing before Presbytery, he had then failed to abide by those assurances and was therefore in contempt. He was then suspended from the exercise of his office and an interim Moderator appointed to the charge. After the granting of an interim interdict suspending the decision of the Presbytery, the case came before the Outer House once more on a motion for the recall of the interim orders.

Counsel for the defenders argued that the matter was one which fell squarely within the jurisdiction of the courts of the Church, on the grounds that it constituted a issue of doctrine, worship, government and discipline in the Church within the terms of Article IV of the Articles Declaratory, and that the proper course for the petitioner was to exercise his right of appeal to the General Assembly against the decision of Presbytery.

The Lord Ordinary [Osborne] concluded that he had no jurisdiction in the matter; and his judgment is worth quoting at some length:

"As I understand the argument for the petitioner, it proceeded upon the basis that, since the powers of the Church had been the subject of parliamentary enactment, it followed that the decisions of the 


\section{JUDICIAL REVIEW AND CHURCH COURTS}

Church, albeit in relation to spiritual matters, fell within the scope of the supervisory jurisdiction of the Court of Session. It appears to me that such a proposition involves a non sequitur. In the first place, it overlooks the fact that, to quote the words of Lord Justice Clerk Aitchson in Ballantyne v. Presbytery of Wigtown ${ }^{35}$.., the Act of 1921 is not an Act of Parliament conferring rights upon the Church, but it is a recognition by Parliament of Articles framed by the General Assembly of the Church as its Supreme Court in the exercise of what it claimed to be its own inherent powers.' Furthermore, '[t]he Act came into operation by an Order of His Majesty in Council on 28th.June, 1926, and then only after the Declaratory Articles had been adopted by an Act of the General Assembly of the Church of Scotland with the consent of a majority of the Presbyteries of the Church. This adoption of the Articles by the free will of the Church after the Act was on the statute book, and as a condition of the Act becoming operative, was a assertion by the Church of its autonomy in matters affecting its own life and polity.' In the light of these observations, it seems to me that the situation of the courts of the Church of Scotland cannot be equiparated with any tribunal created or upon which a power has been conferred by Parliament..."36

The leading case on the subject of judicial review is West v. Secretary of State for Scotland; in it the Inner House set out the current law in considerable detail. Delivering judgment on behalf of the whole court, Lord President Hope stated that:

"the Court of Session has power, in the exercise of its supervisory jurisdiction, to regulate the process by which decisions are taken by any person or body to whom a jurisdiction, power or authority has been delegated or entrusted by statute, agreement or any other instrument." 37

${ }^{35} 1936$ S.L.T. at 654.

${ }^{36}$ Supra.n.33 at 1235

${ }^{37} 1992$ S.L.T.636 at 650 [emphasis added]. 


\section{THE DENNING LAW JOURNAL}

Crucially, however, Lord Osborne distinguished between this elucidation of the supervisory jurisdiction of the Court of Session and the competence of the courts of the Kirk, and concluded that:

"..it is quite plain that the courts of the Church of Scotland do not fall within this [definition] since... it cannot be said that those courts are bodies 'to whom a jurisdiction, power or authority has been delegated or entrusted by statute.' It appears to me that what was achieved in the Act of 1921 was a recognition by Parliament of certain pre-existing inherent powers in the Church of Scotland, rather than the conferring of powers upon it. ${ }^{p 38}$

Lord Osborne noted with approval the obiter of Lord Murray in Ballantyne v. Presbytery of Wigtown, ${ }^{39}$ that the Court of Session had exclusive jurisdiction to determine the meaning and effect of the 1921 Act and the Declaratory Articles. Following Lord Murray's conclusion, he asserted that the remedy of judicial review might be available in certain circumstances; he did not, however, give any indication as to what those circumstances might be.$^{40} \mathrm{He}$ concluded with the passages from Lord President Boyle in Lockhart and Lord Justice Clerk Moncrieff already quoted. ${ }^{41}$

\section{THE FUTURE OF JUDICIAL REVIEW}

Writing in 1992 Lord Mackay of Clashfern, at the time Lord Chancellor, argued that:

"The authority of the Church in matters spiritual is thoroughly recognised, not only by Parliament but also by the courts. This attitude so far as the courts are concerned extends to other churches than the Church of Scotland itself. The courts do not take upon themselves the responsibility of deciding matters of faith. They

\footnotetext{
${ }^{38}$ Supra.n.33 at 1235

${ }^{39}$ Supra.n.35 at 664.

${ }^{40}$ Supra.n.33 at 1236.

${ }^{41}$ Supra.n.6 \& n.8.
} 


\section{JUDICIAL REVIEW AND CHURCH COURTS}

may have to decide as a matter of fact what were the beliefs of a particular organization at a particular time as those beliefs may define the constitution of the organization for whose benefit monies are held in trust." $" 42$

Construed in the narrowest sense possible, this is undoubtedly the case; but it sheds little light on the likely attitude of the courts to a whole range of possible solutions. The crux of the problem is to define "matters spiritual". It is tolerably clear that the substitution by canon law of one communion rite for another, as in Forbes v. Eden, is a spiritual matter rather than a temporal one; it can reasonably be argued that such an action is hardly different in kind from the voluntary association that is the Scottish Rugby Football Union changing the penalty for intentionally collapsing the scrum should it choose so to do. ${ }^{43}$ Equally, there are clear cases in which a patrimonial interest is involved.

Whether the decision of the Synod of the Free Presbyterian Church complained of in Brentall related to a spiritual or to a temporal matter, however, is not at all apparent. Given the importance of the theology of Protest for the history of that Church, did the argument over Protest mean that the matter was a spiritual one? Or was it merely an action for reparation on the grounds of wrongful dismissal? Conversely, the pursuer's conduct in Logan seems to have had little, if anything, to do with "matters spiritual." Mr.Logan's offence was to run a business from his manse without the agreement of his Presbytery and no doubt, from his perspective, there were patrimonial interests involved, both as a Parish Minister and as the proprietor of the business to which his Presbytery had taken exception. But this was never put to the test, since the Court of Session refused to review the decision of a court of the Established Church on what that court had ruled was a disciplinary case under Article IV of the Articles Declaratory.

It would appear, rather, from the foregoing discussion that, at the time of writing, the position of the Kirk vis-a-vis the Court of Session is markedly different from that of the other religious bodies in Scotland. Unlike the situation in England, where the decisions of the judicatories of voluntary associations are

${ }^{42}$ Mackay of Clashfern, Lord, "The Law, the Word, and the Head of the Kirk" in Lamont S. (Ed): Si Andrews Rock: Bellew - London 1992 at 149 [emphasis added].

${ }^{43}$ Though the International Board might have views on the matter! 


\section{THE DENNING LAW JOURNAL}

not subject to judicial review because they lack any element of public law, ${ }^{44}$ in Scotland such voluntary associations are in principle subject to judicial review of their actings - however reluctant the Court of Session may be to involve itself in any particular set of circumstances. For example in Brentall, Lord Dunpark noted (without comment, because the point was not at issue) that the Manual of Practice of the Free Presbyterian (hurch conferred the nobile officium upon the Free Presbyterian Church Synod. ${ }^{45}$ It is no doubt open to any voluntary association in Scotland, religious or otherwise, to confer upon its supreme governing body, if it so wishes, the exercise of a power which it may choose to call the nobile officium - if by that term it means, in effect, "the application of the rules moderated by common-sense." Such a power must, however, be exercised in accordance with the rules of natural justice and must inevitably be subject to judicial review. The nobile officium of the General Assembly of the Kirk, on the other hand, is an entirely different matter. It is identical with that exercised by the Court of Session in civil causes, inhering in the fact that the Assembly is the Supreme Court of the Established Church in ecclesiastical causes; and it is exercised independently.

Commenting on the law as it stood in 1980 and following the dicta of Lord Justice Clerk Moncrieff in Wight ${ }^{46}$ Professor Francis Lyall concluded that:
"So long as the courts of the Church do not act plainly ultra vires, or maliciously, or manifestly unjustly (not merely unjustly) or contrary to some civil enactment, no action will lie to reduce their proceedings, or to obtain redress for any injury they have caused. But this is not the same as a statement that the courts of the Church have absolute independence from review by the civil courts. $\$ 47$

It is clear that the legislative and judicial actings of dissenting ecclesiastical bodies are of the nature of the rules of voluntary associations: binding on the members but on no-one else, and even then, binding only if they have been arrived at by due process. Commenting on what can only be described as a

${ }^{44} R$. v. Chief Rabbi of the United Hebrew Congregations of Great Britain and the Commonwealth, ex p. Wachmam [1993] I W.L.R.1036.

${ }^{45}$ Supra.n.21 at 476 ; see also Lord Ross at 481

${ }^{46}$ Supra.n.4.

${ }^{47}$ Supra.n. 10 at 59 


\section{JUICIAL REVIEW AND CHURCH COURTS}

bizarre judgment by the Episcopal Synod of the Scottish Episcopal Church in 1984 on an appeal by the Vestry of St.Devenick's Church, Beildside, concerning access to that congregation's Register of Baptised Members and Adherents, George W.Patterson asks:
"will the civil courts assume jurisdiction if an ecclesiastical court claims that the law of Scotland has been modified by the association's internal rules, even though according to normal principles of interpretation no such modification is apparent?' ${ }^{488}$

After Brentall, one might reasonable conclude that, providing the court in question was a tribunal of a dissenting Church, the answer to Patterson's question would be in the affirmative.

As to the Church of Scotland, the present writer would suggest that the law on judicial review has been developing since 1980 in such a way as to lead to the conclusion that, for all practical purposes, the General Assembly and the Judicial Commission of the Kirk are currently immune from judicial review of their actings - as, in all probability, are presbyteries and kirk sessions. Up to now, it has been difficult, in the light of Lord Osborne's judgment in Logan, to envisage any circumstances in which the caveat enunciated by Lord Murray in Ballantyne about the power of the Court of Session to interpret the 1921 Act could in fact apply, even though Lord Osborne quoted it with approval. In what circumstances could the Court of Session now intervene? Malice? - but how can one allege malice against a court of the realm? Want of jurisdiction? - but the cases that are heard in the courts of the Kirk are by definition ecclesiastical causes. Procedural irregularity?

But if the Court of Session will not go behind the definition in Article IV, then it will presumably not entertain any arguments about procedural impropriety or disregard of the rules of natural justice. ${ }^{49}$ What may change the situation, however, is the enactment of the Human Rights Act 1998 which incorporates into United Kingdom law Articles 2 to 12 and 14 of the European Convention on

48 Supra.n.20 at 161. The appeal was heard on 20th.December, 1984; because the Episcopal Synod is not a court of the realm it is, of course, unreported.

${ }^{49}$ There remains the possibility of an action for a breach of statutory duty; but, given the nature of their respective responsibilities, this would more likely to be brought against the General Trustees, under the terms of the Church of Scotland (Properties and Investments) Act 1925, rather than against the Assembly itself. 


\section{THE DENNING LAW JOURNAL}

Human Rights and Articles 1 to 3 of the First Protocol thereto, as read with Articles 16 to 18 of the Convention. ${ }^{50}$

In his speech on the third reading of the Bill in the House of Lords, the Lord Advocate, Lord Hardie, addressed the question of whether or not the courts of the Kirk were courts for the purposes of Clause 6 of the Bill. ${ }^{51}$ Section 6(1) of the Act states that "[i]t is unlawful for a public authority to act in a way which is incompatible with a Convention right" and Section 6(3) defines a court or tribunal as a "public authority" for the purposes of 6(1).

Lord Hardie began from the position that the courts of the Kirk:

"do not, as a matter either of their constitution or practice, carry out any judicial functions on behalf of the State. Nor do they adjudicate upon a citizen's legal rights or obligations, whether common law or statutory. They operate in relation to matters which are essentially of a private nature. ${ }^{.52}$

The effect of the 1921 Act was therefore:

"to define the Church [of Scotland] as a non-public or private institution in the sense that its affairs were no concern to the State. The 1921 Act effectively disestablished the Church of Scotland. It would seem to me illogical to say that the State had no interest or jurisdiction over the affairs of the Church and its courts while at the same time saying that those courts were nevertheless courts for the purposes of a public general Act. ${ }^{253}$

He went on to say, however, that the courts of the Kirk might in some circumstances be regarded as "public authorities" for the purposes of the legislation. In particular, he gave the example of proceedings by a kirk session considering disciplinary action against a minister and the requirement under Article 6 of the Convention that there should be "a fair and public hearing. by an 6 of the Act.

${ }^{50}$ The texts are set out in extenso in Schedule 1 to the Act.

51 H.L.Deb.(1997-1998) 5 February $1998 \mathrm{col} .792$. In an amended form, it became section

52 Ibid. col. 794 .

${ }^{53}$ Ibid. 


\section{JUDICIAL REVIEW AND CHURCH COURTS}

independent and impartial tribunal established by law." He went on to suggest that:

"questions might then arise - I emphasise that I am referring to a hypothetical situation - as to whether a kirk session was independent and impartial and, in particular, whether it was established by law. I would have some doubts as to whether a kirk session could be so described...[It] seems to be reasonably clear that there was a period in the history of the Church when much of its administration and government was regulated by Acts of the Scottish Parliament. At that period it would be easy to say that kirk sessions, and indeed the Assembly itself, were "established by law."

However that may have been, it appears to me that the effect of the 1921 Act was to cut the connection between the general law of the land and the administration and government of the Church. That being so, it must be at least doubtful whether the kirk session and the General Assembly could any longer be said to be "established by law." It is also possible that questions might be raised as to whether Church courts present a sufficient appearance of independence and impartiality. ${ }^{.54}$

He concluded that:

"If a Church body to which the Bill applies commits a wrong in convention terms, it would fall to the civil courts to right it. The convention rights are in this context part of the law of the land. The civil courts would investigate the convention issue... in exactly the same way as which they would address any other question arising under the law of the land; for example, a complaint that someone acting on behalf of the Church had committed a delict... The civil courts' task does not, and cannot, involve trespassing on the doctrinal and spiritual interests of the Church..." 55

$\$ 4$ Ibid. at col. 796.

\$5 Ibid. 


\section{CONCLUSION}

Section 13(1) of the Act provides that in determinating of any question arising under the legislation which might "affect the exercise by a religious organisation... of the Convention right to freedom of thought, conscience and religion" the court must "have particular regard to the importance of that right.". It is difficult to see, however, how this might be applied in practice in a purely disciplinary case

The hypothetical example offered by the Lord Advocate, of a claim by a minister that judicial proceedings against him were irregular and therefore contrary to Article 6 of the Convention, was very similar to the argument advanced by the petitioner in Buchan v. Brodie. ${ }^{56}$ On that occasion, as we have seen, the Court of Session refused to go behind the terms of Article IV of the Schedule to the 1921 Act; but would it do so now? Similarly, once one sets aside the power of a presbytery to determine whether or not a case before it is one of discipline under Article IV, then the facts in Brentall $^{57}$ and the facts in $\operatorname{Logan}^{58}$ begin to have a good deal in common. It is clear, therefore, that what was settled law has now become unsettled.

Article IV asserts:

"the right and power subject to no civil authority to legislate, and to adjudicate finally, in all matters of doctrine, worship, government and discipline in the Church..."

In any future action of the kind contemplated by the Lord Advocate, the matter at issue will in all probability be whether or not the judgment of the court which is called into question relates to "functions of a public nature" under section 6(3)(b) of the Act, and whether a case of discipline under Article IV should be so defined - given that Article IV distinguishes between doctrine, worship, government and discipline. The effects of the Act on the exclusive jurisdiction of the courts of the Kirk and on the development of the law in this area therefore remain to be seen.

\footnotetext{
${ }^{56}$ Supra.n.32.

${ }^{57}$ Supra.n. 21

${ }^{58}$ Supra.n. 33
} 